\title{
用語解説
}

\section{外科的糖尿病（surgical diabetes）}

\section{有光 秀仁 ${ }^{1)}$ 鍋谷 圭宏 ${ }^{1,2)}$ 櫻井 健一 ${ }^{3)}$}

はじめに一語源一

糖尿病を術前に指摘されていない患者でも外科

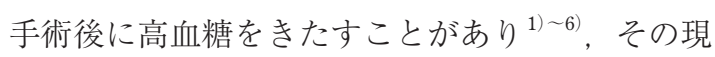
象を外科的糖尿病（英語では surgical diabetes） と呼ぶことがある ${ }^{1)}$.7)。この用語は慣用的に用い られていると思われ, 糖尿病の専門家や内科系の 医師はあまり使わないかもしれないが，代謝や侵 襲学に関心の深い外科系の医師の間では理解しゃ すく, 確立された概念・用語と言って良いと考え られる。しかし，その語源を明らかにするのは非 常に困難である。

日本語としての「外科的糖尿病」は, わが国で は 1980 年に和文論文に使われており ${ }^{8)}$, 現在で は教科書などにも登場する「標準的な」用語と なっている。一方，「 surgical diabetes」は英文論 文では, 1980 年代後半より 1990 年代に登場す $3^{9), 10)}$. この病態を指す他の英語表現としては,

$\lceil$ perioperative hyperglycemia without diabetes $\rfloor$ がある ${ }^{11), 12)}$ 。我々が検索した限りでは，「外科的 糖尿病」の方が古くより使われており, 英文学術 誌ではおそらくその後に「surgical diabetes」が 登場したのではないかと考えられる。そして, こ の英語の表現は, 日本人が作り出した（英米人に 通じない）和製英語ではなさそうである。（もし， 1980 年以前の英文論文での「 をご存じの読者がいらっしゃったら, ぜひご教示 いただきたい.）

\section{外科的糖尿病（surgical diabetes）の病態と臨床 的意義}

外科的糖尿病の病態は, 外科的侵襲が加わるこ とにより交感神経系が賦活化され, カテコールア ミンや各種コルチコイド, 成長ホルモン, グルカ ゴンなどの分泌が充進することにより惹起され る ${ }^{13)}$. これらのホルモンは抗インスリン作用を持 つと共に，インスリン分泌能の低下・インスリン 抵抗性の増大・糖新生とグリコーゲン分解の克進 を生じ, 高血糖となる。この変化が糖尿病患者に 起こると, 症状が増悪することも多いので注意を 要する.

高血糖が生体の防御機能を低下させ, 術後感染 性合併症発生率を高くすることは観察研究より既 知の事実となっているが，そのメカニズムは未だ 完全に解明はされていない ${ }^{14)}$ 。高血糖が感染防御 能を低下させる一連のメカニズムとしては, 好中 球の貪食・殺菌力・走化性に機能低下が生じるこ とと, 高血糖自体が炎症性サイトカインの増加を もたらし炎症反応を惹起・増幅させること, など が考えられる ${ }^{15)}$.

このように, 術後の高血糖は術後感染症予防の 点から回避すべきであるため,「外科的糖尿病」 により発生する術後高血糖（患者ごとにその程度 は異なるが）が，合併症予防の点からどの程度ま で許容されるのか? を知っておく必要がある. すなわち,「外科的糖尿病」の臨床的意義は,「術 後の血糖管理」の意義と換言できるかも知れな w.

\section{外科的糖尿病への対応: 術後の血糖管理}

外科的糖尿病により発生する高血糖は, 患者の
千葉県がんセンター消化器外科 ${ }^{1)}, \mathrm{NST}^{2)}$
$260-8717$ 千葉県千葉市中央区仁戸名町 666-2 君津中央病院内分泌代謝科 ${ }^{3)}$ 
元々の耐糖能や侵襲に対する生体反応の程度によ り異なる。しかし，臨床的には，ある一定のレべ ルに血糖を維持するために適宜インスリンを用い ることが必要になる．インスリン投与の方法はい くつかあるが，速効型インスリンの持続静注が投 与量の微調整が容易であるので，多くの症例の術 後の血糖管理に適していると思われる7)。血糖值 を頻回（投与開始時は 2 時間おき）に測定してイ ンスリン投与量を調節する.

血糖コントロールの目標值としては，2001年 にVan den Berghe ら ${ }^{16)}$ が, 主に心臓手術患者で 血糖を 80〜 $110 \mathrm{mg} / \mathrm{dl}$ にコントロールする強化イ ンスリン療法 (intensive insulin therapy : IIT) の 有用性を報告したことは周知の事実である。しか しその後, IIT では低血糖発作の頻度が高く DM 患者に有益性がそしいとの報告 ${ }^{17)}$ や，術後の患者 でも $180 \mathrm{mg} / \mathrm{dl}$ 以下の血糖コントロールで IIT と 予後に差がないとの NICE-SUGAR Studyの報 告 ${ }^{18)}$ などから, IIT は現在標準的術後管理とはな り得ていない ${ }^{19)}$. (IITについては, 本誌の佐藤 論文 ${ }^{20)}$ ならびに間崎論文 ${ }^{19)}$ を是非参照されたい.） 米国 DM 学会 $(\mathrm{ADA})$ と胸部外科学会 (STS) か ら, 周術期の血糖值は 140〜 $180 \mathrm{mg} / \mathrm{dl}$ が好まし

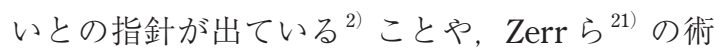
後 48 時間以内の血糖值が $200 \mathrm{mg} / \mathrm{dl}$ 以上の群は それ以下の群に比べて surgical site infectionの発 生率が有意に高いという報告などを考慮すると, 「周術期の血糖值は 150 $200 \mathrm{mg} / \mathrm{dl}$ を目標に，周 術期を通して血糖変動幅を小さくコントロールす るように」注意して管理するのが実際的ではない かと考えている ${ }^{7)}$. 従って,「外科的糖尿病」の 程度がこの範囲を超えていれば，インスリンを用 いて血糖管理すべきであろう。

\section{おわりに}

外科的糖尿病（surgical diabetes）は, 術後管 理において極めて重要な概念である。例え糖尿病 の既往がなくとも, 術前に耐糖能の評価をするこ とは勿論のこと, 術後の血糖管理に細心の注意を
払うことが合併症予防の点から重要であると考え られる。ささらに, 糖尿病あるいは耐糖能異常患者 の手術症例が増加しつつある今日, 外科的糖尿病 （surgical diabetes）という生体反応を積極的に制 御する必要性も高くなる。

\section{文献}

1）吉田 寬, 元井冬彦, 片寄 友ほか: 知っておくべき Poor Risk 患者の周術期管理 - 糖尿病患者の周術期管 理. 外科治療 $98: 362-366,2008$

2) Raju TA, Torjman MC, Goldberg ME et al. : Perioperative Blood Glucose Monitoring in the General Surgical Population. J Diabetes Sci Technol 3 : 1282-1287, 2009

3) Frisch A, Chandra P, Smiley D et al. : Prevalence and clinical outcome of hyperglycemia in the perioperative in non-cardiac surgery. Diabetes Care $33: 1783-1788$, 2010

4) Bower WF, Lee PY, Kong A et al. : Peri-operative hyperglycemia-a consideration for general surgery? Am J Surg 199: 240-248, 2010

5) Gustafsson UO, Thorell A, Soop M et al. : Haemoglobin A1c as a predictor of postoperative hyperglycaemia and complications after major colorectal surgery. Br J Surg $96: 1358-1364,2009$

6) Hanazaki K, Maeda H, Okabayashi T : Tight perioperative glycemic control using an artificial endocrine pancreas. Surg Today $40: 1-7,2010$

7）鍋谷圭宏, 櫻井健一, 坂本昭雄 : 糖尿病症例の周術期 栄養管理. 臨床外科 $66: 756-763,2011$

8）山名泰夫, 遠藤光夫 : 肝硬変合併症例の手術前, 後に 㧍ける Glucose-Insulin-Kalium（G-I-K）療法の臨床 的検討，東京女子医大誌 $50 ： 317-325,1980$

9) Di Carlo, V ; Chiesa, R ; Pontiroli et al. : Pancreatoduodenectomy with occlusion of the residual stump by Neoprene injection. World J Surg 13 : 105-110, 1989

10) Farney AC, Najarian JS, Nakhleh RE et al. : Autotransplantation of dispersed pancreatic islet tissue combined with total or near-total pancreatectomy for treatment of chronic pancreatitis. Surgery $110: 427-437,1991$

11) Mercadal orfila G, Llop Talaveron JM : Effective of perioperative glutamine in parenteral nutrition in patients at risk of moderate to severe malnutrition. Nutr Hosp 26 : 1305-1312, 2011

12) Mraovic B, Suh D, Jacovides C et al. : Perioperative hy- 
perglycemia and postoperative infection after lower limb arthroplasty. J Diabetes Thecnol 5 : 412-418, 2011

13）大村健二：手術侵襲と糖代謝. 外科治療 91 : 659-665, 2004

14) Turina M, Fry DE, Polk HC jr. : Acute hyperglycemia and the innate immune system - clinical, cellular, and molecular aspect. Crit Care Med 33 : 1624-1633, 2005

15）寺島秀夫, 米山 智：侵襲下の血糖值と感染防御能 Tight Glycemic Controlのみで十分なのか〜。外科と 代謝・栄養 $45 ：$ 199-210, 2011

16) Van den Berghe G, Wouters P, Weekers F et al. : Intensive insulin therapy in the critically ill patients. N Eng J Med 345 : 1359-1367, 2001

17) Arabi YM, Dabbagh OC, Tamim HM et al. : Intensive insulin therapy in mixed medical / surgical intensive care units - Benefit versus harm. Diabetes 55 : 31513159, 2006

18) The NICE-SUGAR Study Investigators, Finfer S, Chittock DR et al. : Intensive versus conventional glucose control in critically ill patients. N Eng J Med 360 : 1283 $-1297,2009$

19）間崎武郎，増田英樹，高山忠利：血糖コントロール方 法と合併症発生時に関する臨床報告. 外科と代謝・栄 養 $46: 9-13,2012$

20）佐藤格夫 : Intensive insulin therapy（強化インスリン 療法)。外科と代謝・栄養 43:117-119, 2009

21) Zerr KJ, Furnary AP, Grunkemeier GL et al. : Glucose control lowers the risk of wound infection in diabetics after open heart operations. Ann Thorac Surg 63 : 356361,1997 